\title{
COST OF SUBSTITUTE FACLITIES AS A MEASURE OF JUST COMPENSATION WHEN THERE IS A PRIVATE CONDEMNEE
}

The Constitution provides that private property shall not "be taken for public use, without just compensation."1 The usual measure of "compensation" when a parcel of land is taken by power of eminent domain is the fair market value of the property at the time taken. ${ }^{2}$ However, market value is not the only measure of just compensation, and there are situations where market value either cannot be determined or does not result in "just compensation" to the owner of the property. ${ }^{3}$ As an example, consider the following situation: the

1. U.S. ConsT. amend. V (emphasis added). This provision is the only one in the Constitution concerning the exercise of the power of eminent domain. It is generally conceded that eminent domain is a power of the sovereign, inherent in and inseparable from the idea of sovereignty. Kohl v. United States, 91 U.S. 367, 371-72 (1875). Thus, the Constitution is not the source of the power of eminent domain but serves to limit the exercise of the power in two ways: the property taken must be taken for a "pubhic use," and there must be "just compensation" for the property taken. This Note will focus upon the latter requirennent.

Since the fifth amendment specifically inentions "private property," it might be contended that the cost of substitute facilities doctrine, developed for protection of public property owners, see notes 8-23 infra and accompanying text, is not a measure of compensation under the fifth amendment and need not be extended to similar facilities in private hands. This contention proves inadequate due to the fact that the duty to compensate for public property taken by eminent domain does arise under the fifth amendment:

While the [fifth] amendment reads that "private property cannot be taken for public use, without just compensation," yet "private," as thus used, imcludes property which is ordinarily regarded as public property - such as that held for public uses by a state. United States v. Wheeler Township, 66 F.2d 977, 982 (8th Cir. 1933) (emphasis im original).

Thus, the compensation for public facilities by provision of substitute facilities is clearly compensation under the fifth ameudment.

2. United States v. Cors, 337 U.S. 325, 332 (1949); United States ex rel. TVA v. Powelson, 319 U.S. 266, 275 (1943); United States v. Miller, 317 U.S. 369, 374 (1943). "Fair market value," as used here, means the amount a purchaser willing but not obhiged to buy the property would pay to an owner willing but not obliged to sell it. 4 Nrchols on EMINENT Domain \$ 12.2[1] (rev. 3d ed. 1971).

3. The guiding principle of just compensation is reimbursemeut to the owner for the property interest taken. He is entitled to be put in as good a position pecuniarily as if his property had not been taken. He must be made whole but is not entitled to more. In many cases this principle can readily be served by the ascertainment of fair market value .... Bnt this is not an absolute standard nor an exclusive method of valuation. United States v. Virginia Elec. \& Power Co., 365 U.S. 624, 633 (1961) (citations omitted). 
federal government condemns an ancient church building, still actively used for religious purposes, to build an expressway. The building and land have a "market value" of $\$ 100,000,4$ but due to rising costs the church as it exists today would cost $\$ 200,000$ to replace. In addition, building code regulations, which apply to new but not to existing buildings, would prevent replacement with the same type of building and would add $\$ 100,000$ to the cost of a new church. A court determining just compensation for the property would have to choose the appropriate measure from among market value ( $\$ 100$,$000)$, replacement cost $(\$ 200,000)$ less depreciation, or the cost of substitute facilities $(\$ 300,000)$. When the condemnee is a governmental unit, the cost of substitute facilities has been apphied as a means of determining just compensation for the property taken. ${ }^{5} \mathrm{Re}-$ cently, in United States v. 564.54 Acres of Land, ${ }^{8}$ the Third Circuit became the first federal court of appeals to conclude that the cost of substitute facilities could be applied as a measure of just compensation not only to public owners of nonprofit facilities but to private owners of such facilities as well. ${ }^{7}$

4. For facilities of this type, there is seldom a real market value since few parties engage in the buying and selling of churches. Thus, market value in this case means not the unique value of the building as a church but only the value predicated upon a general use of the facility. This situation generally applies to special-use facilities, regardless of whether operated for profit or not.

5. See notes 8-23 infra and accompanying text for a discussion of the substitute facilities doctrine as applied to public owners of property. For a more detailed discussion, see Note, Just Compensation and the Public Condemnee, 75 YALE L.J. 1053 (1966); Note, The Sovereign's Duty to Compensate for the Appropriation of Public Property, 67 Colum. L. Rev. 1083 (1967).

6. 506 F.2d 796 (3d Cir. 1974).

7. The Southeastern Pennsylvania Synod of the Lutheran Church in America owned and operated several summer camps on land condemned by the United States. The camps had been operated for a number of years at a loss; there was no fair market value for the facilities as a camp; by virtue of grandfather clauses in state legislation the present camps could have continued to operate with somewhat primitive facilities while replacement would require far more elaborate facilities; and the cost of substitute facilities was much higher than any market value that could be attributed to the present facilities. Id. at 798. The lower court had held that the cost of substitute facilities as a measure of compensation was available only to a governmental condemnee. Id. The Third Circuit held that the cost of substitute facilities was available as a measure of compensation to private owners of nonprofit facilities and remanded the case to the lower court for a determination of whether this was a proper case for such application. Id. at 802. This case is the first in which the question has been before a federal circuit court; however, several state courts have considered the question, reaching conflicting results. Compare, e.g., Newton Girl Scout Council, Inc. v. Massachusetts Turnpike Authority, 355 Mass. 189, 138 N.E.2d 769 (1956) (allowing application of cost of substitute facilities where a Girl Scout camp was taken) with State v. First Methodist Church, 6 Ore. App. 492, 488 P.2d 835 (1971) (disallowing application of the cost of substitute facilities where a church youth center was taken). 


\section{The Development of the Cost of Substitute FACILITIES Doctrine}

The cost of substitute facilities doctrine ${ }^{8}$ provides that when a subordinate governmental body ${ }^{9}$ owns facilities being taken by power of eminent domain by a superior governmental body and when the condemnee is required to furnish such facilities ${ }^{10}$ or to continue the services for which the facilities are necessary, just compensation is to be measured by the cost of providing the necessary substitute or replacement facilities. ${ }^{11}$ Courts developed the cost of substitute facilities doctrine to meet the unique needs of public condemnees. When property held by a governmental entity for a public use is condemned, special problems often arise in determining the arnount of compensation that should be paid, simce in most instances the facilities taken are not cominonly bought or sold on the open inarket and are seldom operated for profit. Where such property does have a narket value, the value is often so low that it does not represent the loss sustained by the

8. While the terms "cost of substitute facilities doctrine" and "substitute facilities doctrine" are often used interchangeably, this Note will use only the former so as to avoid confusion with the concept of "substitute condemnation." Substitute condemnation describes the practice in which the condemnor actually condemns other property with which it compensates a condemnee for property taken. See generally Comment, Substitute Condemnation, 54 CALIF. L. REv. 1097 (1966).

9. The term "subordinate governmental body" is used merely to indicate an entity whose property is subject to the eminent domain power of another governmental unit (e.g., a town as compared to a state or the federal government).

At one time, there was a question of the federal government's power to condemn property owned by another governmental unit. However, it is now clear that the federal power of eminent domain is superior to all uses of property by lesser governmental units. United States v. Carmack, 329 U.S. 230, 240 (1946).

10. Courts have limited the application of the cost of substitute facilities doctrine to instances where replacement is a inatter of necessity. Soine courts have required that the necessity be legally mandated while others have adopted a less stringent standard, factual necessity, in determining whether the substitute facility doctrine should be applied. See notes 18-23 infra and accoinpanying text. Regardless of the test applied, it is clear that if a facility taken is no longer in use or is used only sporadically, the courts will not award the cost of substitute facilities as just compensation.

11. E.g., California v. United States, 395 F.2d 261 (9th Cir. 1968); United States v. Certain Land, 346 F.2d 690 (2d Cir. 1965); United States v. Certain Lands, 246 F.2d 823 (3d Cir. 1957). The Supreine Court apparently recognized the cost of substitute facilities doctrime in Brown v. United States, 263 U.S. 78 (1923), a case upholding the constitutionality of a statute authorizing the government to condemn additional property adjacent to land to be flooded by a dain and reservoir project as a substitute site for the purpose of relocating a town situated within the project:

A town is a business center. It is a unit. If three-quarters of it is to be destroyed by appropriating it to an exclusive use ...., all property owners, .... as well as the State, whose subordinate agency of government is the municipality, are injurcd. A method of compensation by substitution would seem to be the best means of making the parties whole. Id. at 82-83. 
owner, the public condemnee. ${ }^{12}$

The purpose of the cost of substitute facilities doctrine is to ensure that sufficient damages will be awarded to finance a replacement for the condemned public facility. ${ }^{13}$ Therefore, the ineasure is used not only when there is no market value for the property taken, but even where there is a market value. In the latter situation, the cost of substitute facilities measure is used regardless of whether the award it produces is greater than or less than the value of the property. ${ }^{14}$

The presumption of a community interest im the continuation of the faeilities, or the services available through the facilities, precludes the application of the replacement cost less depreciation standard as the ineasure of compensation wlien public facilities are taken. Generally, there is no reduction in the award for the amount of depreciation when the cost of substitute facilities is used as the measure of compensation as there is when the measure of coinpensation is replacement

12. Market value for governmental facilities as such does not exist; thus market value in this context gauges the worth of the facility for general use, not the special use for which it is provided. For example, public schools are rarely bought and sold on the market as "schools" although a school may be purchased for some general use, such as a warehouse. That market value is likely to be substantially lower than the cost to the community of providing the school. The excess cost to the community of providing the new school is the loss sustained by the condemnee.

13. It should be noted that the cost of substitute facilities doctrine does not require exact duplication of the facilities taken. The replacement need only be functionally equivalent; the equivalence required is one of utility. United States v. Certain Property, 403 F.2d 800, 804 (2d Cir. 1968); United States v. Board of Educ., 253 F.2d 760, 764 (4th Cir. 1958).

14. Fort Worth v. United States, 188 F.2d 217 (5th Cir. 1951); United States v. Des Moines County, 148 F.2d 448 (8th Cir.), cert. denied, 326 U.S. 743 (1945). This result rests upon the rationale that the community is made "whole" by the provision of substitute facilities, and that this is all that is required by the fifth amendment. "[The landowner] is entitled to be put in as good a position pecuniarily as if his property had not been taken. He must be made whole but is not entitled to more." Olson v. United States, 292 U.S. 246, 255 (1934). However, it is arguable that the "fair market value" measure of just compensation should be applied when the facility taken has a substantial market value. The substitute facilities doctrine was developed originally to deal with the taking of roads, bridges, and similar facilities, which by their nature are not likely to have value independent of the use they serve. When the property taken is a public building in a commercial district, the building has the value to the governmental unit of the use it serves but it also has value to the governmental unit in the amount of the price it would bring if sold on the open market. "Just compensation" or "making whole" would seem to require consideration of both values, the nieasure of compensation being determined by the greater.

In accordance with this rationale, the Third Circuit in the 564.54 Acres case indicated that when a private landowner is ehgible for the cost of substitute facilities, he would be entitled to the greater of the two measures, market value or cost of substitute facilities, since he has a proprietary interest as well as community interest in the property. 506 F.2d at 800 . 


\section{cost less depreciation..$^{15}$}

In addition, the use of replacement $\operatorname{cost}^{16}$ alone is not always sufficient since it is based upon a duphication of the existing facilities when duphication may no longer be adequate to meet statutory or regulatory requirements for such facilities. ${ }^{17}$ By awarding the cost of substitute facilities, there is an assurance which replacement cost does not provide that the facilities and their related services can continue to exist (i.e., where depreciation in the original facility has been substantial or where a replacement of the same facility would no longer be acceptable due to more stringent building code requirements).

Courts that have applied the cost of substitute facilities doctrine when there is a taking of public property by a superior governinental unit have agreed that the measure is used only when replacement of the facility taken is "necessary." 18 The courts have reasoned that if the governmental entity involved does not need to provide a substitute for the property taken, it has suffered no loss apart froin the market value of the property, which is usually very low. ${ }^{19}$

15. See, e.g., Town of Clarksville v. United States, 198 F.2d 238 (4th Cir. 1952), cert. denied, 344 U.S. 927 (1953); Town of Bedford v. United States, 23 F.2d 453 (1st Cir. 1927). But see United States v. Certain Property, 403 F.2d 800, 804 (2d Cir. 1968). In the latter case the court upheld the use of the cost of substitute facilities as the measure of damages but indicated that the substitution cost should be discounted by reason of the benefit which accrues to the condemnee when the new building replaces one with expired useful years. A method of valuation which fails to allow for depreciation in effect gives a bonus to the municipality whose structure is taken, since it has received the use of the structure at no cost. See notes 56-59 infra and accompanying text for the proposition that disregarding the amount of depreciation is necessary to achieve the objectives of the cost of substitute facilities doctrine.

16. While the terms "cost of substitute facilities" and "replacement cost" are often used interchangeably, for this Note "replacement cost" will mean the cost of replacing the condemned facility as it exists at the time of condemnation while "cost of substitute facilities" will mean the cost sufficient to provide for continuation of the facility, sometimes a quite different amount.

17. Examples would be requirements that all new construction take place on certain minimum-sized lots, include certain safety features not required of older buildings, or include certain sanitation features not required of older buildings. (An analogous situation would be the present requirement that all new cars have anti-pollution devices.) The distinction between replacement cost and cost of substitute facilities does not include inadequacy caused by increased use of the facility (i.e., a church built for 100 people but now used by 300 ) or inadequacy caused by the outmoded nature of existing facilities.

18. E.g., United States v. Certain Property, 403 F.2d 800 (2d Cir. 1968); California v. United States, 395 F.2d 261 (9th Cir. 1968); United States v. Certain Land, 346 F.2d 690 (2d Cir. 1965). All the courts applying the cost of substitute facilities doctrine have applied the requirement that replacement be a "necessity," though soine require it to be a "legal necessity" while others only require that it be a "factual necessity." See notes 20-34 infra and accompanying text.

19. E.g., United States v. New York, 168 F.2d 387 (2d Cir. 1948). The taking in- 
Some courts have held that there exists a necessity to replace public facilities only where such replacement would be legally mandated. ${ }^{20}$ The rationale behind the legal necessity test is that if the governmental unit is not required to replace the facility, there can be no loss. ${ }^{21}$ The requirement of legal necessity disregards the fact that the mere existence of the facility supposedly represents a choice by the community that the facility exist and at least a perception that the facility provided a benefit to those who used it. Thus, the condemnation of such a facility causes a loss to the community, regardless of whether replacement is "required." This loss becones more obvious when the facility is one which the members of the community would choose to replace. In such a case, the community must bear the cost of the new facility while receiving only nuarket value, a conipensation usually insufficient to ensure continuation.

Other courts, rejecting the requirement that the replacement of the facility be a matter of legal necessity, have adopted a test of "factual necessity."22 The "factual necessity" standard provides that if the condemned facility is reasonably necessary to the public welfare, compensation equal to the cost of substitute facilities is to be provided. ${ }^{23}$ When the standard is "factual necessity," the burden rests upon the condemnee to show that there exists a necessity reasonably related to public welfare. Thus, while the term "necessary for public welfare" causes definitional problems in this context, the "factual necessity" test gives a court greater latitude than the more easily interpreted "legal necessity" standard.

\section{Extension of the Cost of Substitute Facilities Doctrine to Private Condemnees}

A court which applies the "legal necessity" standard clearly would be unwilling to extend the cost of substitute facilities doctrine

volved certain streets for which there was no necessity for replacement. The court held that the city was entitled only to the cost of substitute facilities, and if there was no "necessity," the city suffered only nominal damages. The court reasoned that the city really had been relieved of the burden of maintaining such unnecessary streets.

20. E.g., United States v. Board of Educ., 253 F.2d 760, 764 (4th Cir. 1958); United States v. Wheeler Township, 66 F.2d 977, 985 (8th Cir. 1933).

21. E.g., Woodville v. United States, 152 F.2d 735 (10th Cir. 1946); United States v. Wheeler Township, 66 F.2d 977, 985 (8th Cir. 1933).

22. E.g., United States v. Certain Land, 346 F.2d 690 (2d Cir. 1965); United States v. Certain Lands, 246 F.2d 823 (3d Cir. 1957). In the former case, the court said that the necessity rule "Iooks to the pragmatic needs and possibilities, not just to the technical legal minima." 346 F.2d at 695.

23. United States v. Certain Property, 403 F.2d 800, 804 (2d Cir. 1968). At least 
to private nonprofit landowners since there can never be a legal obligation to maintain such facilities. For example, in State v. First Methodist Church, ${ }^{24}$ an Oregon court refused to apply the substitute facility measure of damages where a church youth center was taken by eminent domain. The court concluded that the application of the cost of substitute facilities doctrine was limited to the situation "where the property taken performs a legally necessary function."25 The court poimted out that "[d]esirable as it may be for the church to operate the youth center, it had no legal duty to do so."26

On the other hand, the Third Circuit in United States v. 564.54 Acres of $L a n d^{27}$ rejected the position that only a "governmental entity under a legal obligation to replace a condemned facility should be entitled to indemnification to the extent of the substitute facilities measure of just coinpensation," ${ }^{28}$ and concluded that the cost of substitute facilities is available to private owners of nonprofit community facilities as well. The court based this result on the ground that the Government's position "would produce the anomalous result that the federal government's fifth amendment duty of fair compensation, which would seein to be equally applicable throughout the country, would vary according to the vagaries of local law."29 The Third Circuit appears to have adopted the standard enunciated by the Second Circuit

one commentator has suggested that even a "factual necessity" test is inappropriate and that the correct approach would be to determine whether a proposed substitute would serve a rational governmental purpose. Note, Just Compensation, supra note 5, at 1055.

24. 6 Ore. App. 492, 488 P.2d 835 (1971). The court held that the "substitute facility" theory, rather than market value, was not appropriate for evaluation of a church youth center building where the facility was not one which the condemnee had a legal duty to maintain.

25. Id. at 495,488 P. $2 \mathrm{~d}$ at 837 .

26. Id. at 496,488 P.2d at 837 . The problem with the decision is that the court's requirenent that there be a legal necessity for replacement of the facility taken is based upon two cases, United States v. Certain Land, 346 F.2d 690 (2d Cir. 1965), and United States v. Board of Educ., 253 F.2d 760, 764 (4th Cir. 1958), which are in conflict as to the correct result. The Second Circuit case, United States v. Certain Land, stands for the proposition that "'necessity' . . . looks to the pragmatic needs and possibilities, not just to technical legal minina." 346 F.2d at 695 . Had the court correctly interpreted that case, it is questionable whether the conclusion that there must be a legal necessity for the facilities to be replaced would have been reached. It should be noted that the court also denied recovery of the cost of substitute facilities on an alternative rationale, that the usual methods of demonstrating market value did exist in this case. See note 59 infra and accompanying text for the proposition that market value should not be relevant where the case is otherwise appropriate for application of the cost of substitute facilities doctrine.

27. 506 F.2d 796 (3d Cir. 1974).

28. Id. at 800 .

29. Id. 
in United States v. Certain Property, ${ }^{30}$ that if a condemned facility is reasonably necessary for public welfare, then "compensation is measured not in terms of 'value' but by the loss to the community occasioned by the condemnation." 31 Under this standard, the question of reasonable necessity is a factual one, to be determined by the trial court. ${ }^{32}$

The Third Circuit did not determine in 564.54 Acres of Land whether there was actually a factual necessity for replacenient of condemned camp facilities, ${ }^{33}$ nor did the court give the lower court any guidance on the factors to be considered when resolving that issue. Given the nebulous nature of the question of factual necessity when public facilities are involved, the problem is only exacerbated when private facilities are taken. One can imagine the problems arising when a jury determines as a factual matter that there is no need to replace a recreational center run by blacks or that replacement of a church of an unconventional faith is not needed, while another jury determines that the local YMCA or Baptist church is certainly necessary to the public welfare and applies the substitute facilities measure of damages. ${ }^{34}$

If the courts are to apply the cost of substitute facilities measure of compensation to privately owned nonprofit facilities, there is a need to develop a new and clearer standard for determining the necessity of the condemned facility in terms of the public welfare. Two approaches could be taken in the formulation of this standard. The first approach would be to create an irrebuttable presumption that a private nonprofit facility is "necessary."35 While attractive on its face because of apparent ease of: application, this rule would result in a

30. 403 F.2d 800 (2d Cir. 1968).

31. Id. at 804 .

32. Id.

33. 506 F.2d at 802 . The Third Circuit only decided that the cost of substitute facilities doctrine could be applied to private condemnees as well as public condemnees. The actual determination of whether the present case was appropriate for such application was left to the district court.

34. See Comment, The Lord Buildeth and the State Taketh Away-Church Condemnation and the Religion Clauses of the First Amendment, 46 U. CoLo. L. REv. 43 (1974) (discussion of the potential first amendment problems arising when a decision to condemn church property is made). Many of these same problems arise when the determination is to be made as to whether a certain religious facility is "factually necessary." See also notes 53-55 infra and accompanying text for the potential problems when a condemnor must choose between condemning public property and church property.

35. "Nonprofit" facilities would have to be satisfactorily defined. An example would be to provide that any facility owned by an organization which qualifies for the charitable organization exemption from federal income taxation under section 501 (c) (3) of the Internal Revenue Code would be considered "necessary." 
greater protection to privately owned facilities than is currently extended to similar facilities owned by local governmental units. With regard to public facilities, substitution n1ay be unnecessary; the public need may no longer exist or adequate alternative facilities may be available. $^{36}$ Alternatively, the condemnor's new facilities may serve the same public interest as well as or better than the condemned facilities. ${ }^{37}$ Thus, to consider all facilities owned by a nonprofit organization as "necessary" would be imappropriate, particularly in hight of the fact that the substitute facilities doctrine does not provide such broad coverage to public condemnees, whose needs it was developed to protect.

A second approach would be to niodify the standard proposed by one commentator for public condemnees: ${ }^{38}$ that the only issue as to necessity should be whether the proposed substitute would serve a rational governmental purpose. The modified standard would estabhisl a rebuttable presuntption that facilities owned by a nonprofit organization ${ }^{39}$ are "necessary" in the sense of having a purpose rationally related to the public welfare. The government then would have the burden of showing that the facility has no purpose rationally related to public welfare in light of existing circumstances. Given this standard, a court is no longer faced with the problent of determining the "factual necessity" of a facility owned by a nonprofit organization. On the contrary, the court can assume that a facility nieets the requirement of necessity, until the government denionstrates that the facility is not desirable, convement, attractive, or otherwise beneficial. If the courts are unwilling to adopt such a standard for determining necessity, the extension of the cost of substitute facilities doctrine to private condemnees niay be theoretically possible but realistically impossible due to the problent in determining when such facilities are "factually necessary" to the community welfare.

36. E.g., United States v. City of New York, 168 F.2d 387 (2d Cir. 1948).

37. E.g., United States v. Arkansas, 164 F.2d 943 (8th Cir. 1947); Jefferson County v. TVA, 146 F.2d 564 (6th Cir. 1945).

38. Note, Just Compensation, supra note 5. Although the Note has been cited by several courts in their opinions, e.g., United States v. 564.54 Acres of Land, 506 F.2d 796, 800 (3d Cir. 1974); United States v. Certain Property, 403 F.2d 800, 803 (2d Cir. 1968), no court has specifically accepted the proposed standard.

The reason that the standard nust be modified with regard to private condemnees is that it is framed in terms of "rational governmental purpose." While "rational governmental purpose" is applicable to property owned by a public condemnee, it is doubtful that the concept is useful when property is owned by a private condeinnee. The proposed standard, "some purpose rationally related to public welfare," could be applied not only when there are private condemnees but public condemnees as well.

39. See note 35 supra for a suggested definition of "nonprofit organization." 
Even assuming that the problem in applying the requirement of "necessity" can be surmounted, the basic policy issue of whether the cost of substitute facilities doctrine should be extended to private condemnees would still be unresolved. When there exists a fair market value for the facilities condemned and when such facilities are operated for profit, there has been no suggestion that the usual measure of "just compensation," fair market value, is inadequate. ${ }^{40}$ Even where the property, due to its unique nature, has no market value, courts have found that when such property is operated for profit, "just compensation" can be achieved by giving the owner the present value of the capitalized earnings from the facility. Thus, it is only with regard to facilities operated for other than profit motives and which, because of their umique nature, lave no market value or liave a market value so low that such compensation would result in injustice to the owners and the public, ${ }^{41}$ that the issue is presented. ${ }^{42}$

The Third Circuit in 564.54 Acres of Land relied upon language by the Supreme Court indicating that fair market value is not an absolute standard and that courts should be willing to depart from it when equity requires. ${ }^{43}$ In the case of privately owned special-use property, where there is a linnited market value, or none at all, courts

40. See note 2 supra and accompanying text. The fact that fair market value is compensation for the owner is obvious since the condemnee can readily replace the property in the marketplace at a cost equal to the condemnation award. While there may exist a public interest in seeing such facilities continued, it may be assumed that if profitable, the free market mechanism will function so that a replacement will be provided by some entrepreneur.

41. Loss results to the public because the lower market value will be inadequate to ensure replacement. Injustice results to the owners since, when someone operates a nonprofit facility, one assumes that his "value" results from the satisfaction of providing the facilities to benefit others, not the monetary value of the facility. If the facility is not replaced, the "value" to the owner is lost.

42. An example of this would be a church with a market value of $\$ 100,000$ (assuming that such market value is for the facility for general purposes and that there exists no local market for churches, as such) but which would cost $\$ 300,000$ to replace.

43. Our prior decisions have variously defined the "just compensation' that the Fifth Amendment requires to be made when the Government exercises its power of eminent domain. The owner is entitled to fair market value, but that term is not an absolute standard nor an exclusive method of valuation. The constitutional requirement of just compensation derives as much content from the basic equitable principles of faimess as it does from technical concepts of property law. 506 F.2d at 799, quoting United States v. Fuller, 409 U.S. 488, 490 (1973) (citations omitted).

It should be pointed out that the language involved comes from a case where the Court determined that market value provided too high a level of compensation, and it has been suggested that the Court may be more willing to depart from fair market value as a measure of compensation when such departure results in benefit to the government. Kanner, Condemnation Blight: Just How Just is Just Compensation, 48 NoTRE DAME Law. 765, 808 (1972). 
have been willing to consider the reproduction or replacement cost, less depreciation, as a measure of compensation. ${ }^{44}$ However, such a formula fails to allow for the situation where continuation of the function provided through the facility would be impossible due to a great amount of depreciation or a change in circumstance which would prevent substitution with the same type of facility. ${ }^{45}$ Such was the situation in 564.54 Acres of Land where a camp run by the Lutheran Church was of low market value and where the reproduction of the facilities would have been legally inadequate due to statutory provisions relating to the standards newly constructed camps must meet. $^{46}$

Generally, the private property owner's interest in continuation of his facilities is considered irrelevant to the determination of just compensation. ${ }^{47}$ When a nonprofit organization is a condemnee, it is deprived only of the market value of the property; if there is any loss from the failure of the continuation of the facility, it is that which the public suffers in losing the benefit of the operation of the property. ${ }^{48}$ Thus, the determinative question is whether the public has a sufficient interest in seeing such nonprofit facilities continued that the condemnor should be required to provide an amount adequate to ensure such continuation. When the property is publicly owned, this public loss is what the substitute facilities doctrine, under the "factual necessity" test, $^{49}$ is designed to compensate. While placing the compensation in the hands of the condemnee, it actually ensures that the public as a whole is compensated for the deprivation of the facilities by enabling the acquisition of substitute facilities. ${ }^{50}$ Assuming that there exists a

44. 4 Nichols on EMINENT Domain § 12.32[3][b] (rev. 3d ed. 1971); see, e.g., Orleans Parish School Bd. v. Paternostro, 236 La. 223, 107 So. 2d 451 (1958).

45. See notes $15-17$ supra and accompanying text.

46. 506 F.2d at 798.

47. See, e.g., Mitchell v. United States, 267 U.S. 341 (1925) (where fact that land was particularly suited to condemnee's business was irrelevant in determining compensation). See generally D. Hagman, Urban Planning and Land Development Control LAw 339 (1971).

48. This, of course, excludes any psychological benefit the owner may receive from carrying on activities to benefit others or any benefits he may believe might accrue in a later life due to his works during the present life. See, e.g., 2 Corinthians 5:10 (Revised Standard): "For we must all appear before the judgment seat of Christ, so that each one may receive good or evil, according to what he had done in the body."

49. See notes 22-23 supra and accompanying text. This is true to a larger extent when the "legal necessity" test is applied since in that situation the public owner is being protected only against being legally forced to replace the facility, and thus it is less clear that there is a concern about the loss of the facility to the general public.

50. The requirement that the facility be one that is going to be replaced wonld support this conclusion since, if it is not one that would be replaced, the provision of such 
perceived public benefit in clraritable nonprofit activities, ${ }^{51}$ the "just compensation" for condemned facilities conducting sucli activities should recompense the loss of the public benefit from the operation of the facility. There is no justification for treating privately owned property in a manner different from public property when the interest taken, the general public's interest in the continued use and benefit of the facilities, ${ }^{52}$ is the same.

An additional reason for extending the cost of substitute facilities doctrine to privately owned nonprofit facilities is to prevent the government from determining the site of a project on the basis of the anticipated cost of acquiring the necessary land when the facilities on the potential sites are identical except for ownership, one being public, the other being private. ${ }^{53}$ The compensation required for the public property would be the cost of substitute facilities (relatively high) while the compensation required for the private facilities would be market value (relatively low). While such a result might be avoided by preventing the government from abusing its discretion in determining the location for a project, the wide discretion allowed the government in its planning would prevent effective enforcement. ${ }^{54}$ The

money will in no way compensate the public for the loss of the facility. However, it is also arguable that this requirement exists merely to guarantee that the public owner does not receive a windfall when the facility is not to be replaced.

51. For example, Congress has given nonprofit organizations special treatment in certain circumstances because of the supposed public benefit that results from charitable endeavors. See, e.g., INT. REv. CODE OF 1954, § 501(c)(3) (granting exemptions to charitable organizations from income taxation); id. $\$ 170$ (providing for certain deductions for taxpayers making contributions or gifts to qualifying charitable organizations).

52. As the Third Circuit said:

We are not dealing with congressional largess toward governmental entities, which might justify a distinction between the measure of fair compensation for governmental and for non-governmental community facilities. Rather we are dealing with judicial interpretation of the taking clause. Accepting the interpretation that it protects the value of community uses, there is no basis for distinguishing between governmental and private community uses. 506 F.2d at 801 .

While the cost of substitute facilities doctrine, when applied to the taking of public property, is intended to provide compensation to the interests of the public as a whole in the lost facility, the fifth amendinent provides no reason for not extending the same protection to community values when the property taken is privately owned.

53. Consider, for exainple, choosing "between a highway route traversing land occupied by a private or a public university; the condemnation for emergency office use of a parochial school or a public school; the destruction of a church rather than a city hall to permit the building of a federal courthouse." Id.

54. Generally, judicial review of condemnation proceedings is limited to the question of whether the taking is for a "public use" and whether it is a matter of "necessity." While "necessity" may include the need to take particular property rather than soine other, its determination is regarded as a inatter of legislative discretion. There is no judicial issue of necessity absent a showing of fraud, bad faith, or abuse of discretion. Such a showing is difficult. See generally D. HAGMAN, supra note 47, at 315-16. 
better approach would appear to be to remove all temptation for abuse by establishing a system in which the cost of taking community facilities would be the same, regardless of whether the facilities were publicly or privately owned. ${ }^{55}$

However, there are several practical difficulties in applying the cost of substitute facilities doctrine to privately owned property. First, while the Third Circuit made no specific mention of the treatment to be accorded the depreciation of the facilities involved, there is an indication that the factors necessitating application of the cost of substitute facilities measure preclude the deduction of depreciation from the amount awarded, since to do so might prevent continuation of the facilities. ${ }^{56}$ However, the Second Circuit lias lield that when the cost of substitute facilities doctrine is applied to buildings owned by a public condemnee, "equitable principles undergirding just compensation require that the substitution cost be discounted by reason of the benefit which accrues to the condemnee when a new building replaces one with expired useful years." ${ }^{\text {" } 7}$ The basis of this position is that failure to consider depreciation will result in a windfall to the owner, one that would not occur had the measure of compensation been fair market value. Such reasoming is correct if the cost of substitute facilities doctrine is accepted as coinpensating only the owner of the property taken. However, if one accepts the proposition that the purpose of the

55. While the exercise of the eminent domain power over property held by a church does not violate the "free exercise" clause of the first amendment, the taking of church property rather than some other property merely because the measure of compensation applied would result in a lower cost for such property would raise first amendment probleins. See generally Comment, supra note 34 .

56. Fair indemnification im such circumstances requires compensation sufficient to provide a substitution for the unique facilities so that the functions carried out by or on behalf of meinbers of the community may be continued. Depreciated replacement cost often will not permit continuation of such functions. To meet the requirement of fair indemnification for the taking of community facilities the courts have developed the "substitute facilities" measure of compensation. 506 F.2d at 799-800.

While depreciated replacement cost is also madequate when replacement of the facility with an identical facility will no longer be allowed due to more stringent building requirements, it would appear the court was referring to inadequacy resulting from a reduction of the award as a result of depreciation as well.

57. United States v. Certain Property, 403 F.2d 800, 804 (2d Cir. 1968). See also Note, The Sovereign's Duty to Compensate, supra note 5, at 1118-19:

A method of valuation which fails to allow for depreciation would in effect give a bonus to the municipality whose structure is taken. It is true that the choice to take particular public property inay cause a unit of government to rebuild at an inconvenient time. But this sort of inconvenience is not usually considered a compensable burden; it is disregarded when the measure of damages is market value-which necessarily takes account of depreciation.

But see State v. Waco Independent School Dist., 364 S.W.2d 263 (Tex. Civ. App. 1963) (holding that there should be no deduction for depreciation when applying the substitute facilities doctrine). 
cost of substitute facilities measure is to compensate those who have an interest in the continued operation of the facility, i.e., the public, this purpose is frustrated by deducting the amount of depreciation from the award. The loss being compensated is the deprivation of the benefit of the facilities; the substitution cost is provided to ensure the continued availability of the facilities. To deduct the cost of depreciation is to deprive the public of the right to be made "whole" by having the facilities available for its use and benefit. ${ }^{58}$

In addition, the fact that sucli depreciation would be deducted were market value the measure of compensation is irrelevant since the cost of substitute facilities measure is not a means of "valuation," an "exception carved out of the market value test," native means of determining just compensation. As such, the courts are not bound by the consideration of what the owners would have received had the "market value" test been applied.

58. The "windfall" problem can be illustrated through two hypothetical situations modeled on the 564.54 Acres of Land fact setting. A church may own a recreational or other facility which had a sixty-year projected life when constructed. Only five years of that projected life remain, and church officials already are in the planning stages of a fund-raising drive to pay for a new facility. Should the government decide at this point to condemn the property, the cost of substitute facilities doctrine would require a payment sufficient to finance construction of a new sixty-year facility (since construction of a temporary replacement would most likely be inadequate). But forcing the government to finance the entire cost of the new facility would relieve the church of the burden it was already preparing to undertake. In this situation, however, the trial judge's discretion could be invoked to find that the insubstantial remaining useful life of the facility means that the building itself is no longer of such benefit to the public that the cost of substitute facilities should be borne by the condemning party. Market value would be a more appropriate neasure of damages.

A slightly altered hypothetical, however, presents a more difficult situation. If the ehurch property, with a sixty-year life at construction, has been used for only thirty years when the state makes its condemnation decision, the need for application of the cost of substitute facilities doctrine is greater. Discounting the measure of damages paid for the "depreciation" could make it difficult for the church to finance its part of the replacement cost. For instance, a private organization which is in the midst of another building project may have taxed its financial resources to the limit and be unable to generate the funds to pay for the "depreciation." In this situation, the church would be confronted with a choice of attempting to use the state funds to build a temporary replacement or a much smaller facility, or channeling the state funds into some other endeavor. In either event, the public would be deprived, at least partly, of the benefit it had received from the condemned facility. Alternatives available to the court are permitting a "windfall" to the private owner, or forcing the public beneficiary to forego use of the facility. Here, the same policy arguments supporting the cost of substitute facilities doctrine urge that the condemning government pay the "windfall" price as part of the cost of taking the property. Theoretically, a charge might be imposed on the private owner at the end of the projected useful life of the condemned structure; however, the practical barriers to such an approach are manifest.

59. 403 F.2d at 803. See also California v. United States, 395 F.2d 261, 266 (9th Cir. 1968). 
Another difficulty can arise when it can be shown that the facilities taken would not be replaced, for example, due to their obsolete nature or lack of current use. ${ }^{60}$ In such a situation the private owner of nonprofit property should be entitled only to the market value of the property taken. If the facility is no longer of benefit to the public, there is no need to guarantee continuation of the facility, the reason for application of the cost of substitute facilities measure of compensation. Further, the only loss suffered by the condemnee would be the market value of the property since he will expend nothing to replace the facility. A related problem is that there is no assurance that, once awarded the cost of substitute facilities, the owner will actually use the award to replace the facilities. While this might present a serious problem were the cost of substitute facilities measure of compensation extended to owners of profit-making facilities, there is no reason presently to believe that the recipients will not use the award for the purpose given. None of the state courts which have applied the doctrine to private condemnees has seen need to consider the problem, ${ }^{61}$ nor have the federal courts when applying the doctrine to public condemnees. ${ }^{62}$ While the requirement of "legal necessity" for replacement may have been designed to meet the problem, the movement to the "factual necessity" standard would indicate that courts have not found the possibility of non-continuance to be significant. It would not appear reasonable to assume that when an organization has gone to the cost of providing facilities which provide a direct benefit to others besides itself, there will be a sudden change of motivation when the facilities are condemned, resulting in the misuse of funds. ${ }^{63}$

A more difficult problem arises when the fair market value of the property taken exceeds the cost of the substitute facilities for the property. ${ }^{64}$ Several courts have indicated that when the cost of substi-

60. An example is a church still standing but no longer used to hold services. The property would no longer have the unique function necessitating application of the cost of substitute facilities doctrine.

61. E.g., Newton Girl Scout Council, Inc. v. Massachusetts Turnpike Authority, 355 Mass. 189,138 N.E.2d 769 (1956).

62. E.g., United States v. Certain Property, 403 F.2d 800 (2d Cir. 1968); United States v. Certain Land, 346 F.2d 690 (2d Cir. 1965).

63. In addition, in the usual situation where the organization is a tax-exenpt organization, its favorable tax status would probably be endangered. See, e.g., INr. REv. CODE of 1954, $\$ 501(\mathrm{c})(3)$ (which provides that no portion of the net earnings may inure to the benefit of a private shareholder or individual).

64. For example, a nonprofit facility operated in a conımercially desirable area may have a high market value although the facility could be functionally replaced for a lower amount by rebuilding in another area (assuming the location is not critical to the function of the building). 
tute facilities doctrine is applicable, it slould be used regardless of whether market value is lower or higher than the cost of substitute facilities. ${ }^{65}$ However, these cases involved a unique situation, the taking of public streets. Streets are considered to be held in trust for the public and the legal title to the land over which they run often reposes in the abutting property owners rather than the governmental unit. ${ }^{60}$ Thus, the public condemnee suffers no loss since it really owns nothing of value if the roads are not replaced. The situation is different where the facility involved has a value independent of that created by the purpose for which it exists. ${ }^{67}$ In that case, the proprietary interest of the condemnee cannot be ignored since the owner would not be inade "whole" within the fifth amendment by compensation which provided less than the value of the proprietary interest. The cost of substitute facilities measure, developed to compensate the public interest in the facility where market value would be insufficient to do so, would not constitute just compensation to the owner when the value of the property exceeded the cost of substitute facilities. Thus, in effect, the cost of substitute facilities acts as a minimun level of compensation, with the higher compensation allowed where the proprietary value of the facility outweighs the replacement cost. The public interest in the continuation of the facilities is protected simce the owner presumably will use a portion of the award to provide substitute facilities (if one accepts the proposition that owners of charitable nonprofit facilities will continue to have the same motivations which originally led them to provide such facilities).

\section{CONCLUSION}

Whether the cost of substitute facilities measure of compensation should be extended to privately owned nonprofit facilities requires consideration of two important factors. The first is the definition of the requirement of necessity for replacement of the facility taken. If the "legal necessity" test is applied, extension of the measure to privately owned facilities will be impossible. However, even the "factual necessity" test, because of its nebulous nature, presents probleins that nake extension difficult. The solution is a more lenient standard, a

65. Fort Worth v. United States, 188 F.2d 217 (5th Cir. 1951); United States v. Des Moines County, 148 F.2d 448 (8th Cir.), cert. denied, 326 U.S. 743 (1945). 1950).

66. 10 E. MCQuillen, The LaW of Municipal Corporations $\$ \$ 30.32-36$ (3d ed.

67. For example, a large building in a commercial area, used as a private school, would have value to the condemnee even if it were not a school since alternative uses presumably are possible. See note 14 supra and accompanying text. 
presumption of necessity, "necessity" being defined as having some purpose rationally related to public welfare, with the burden of rebuttal on the government.

The second factor is whether a meaningful distinction can be made between public and private condemnees, justifying a difference in treatment. In this regard, the cost of substitute facilities ineasure should be viewed not as compensating the owner of the facilities but as indemnifying those who have an interest in the continuing existence of such facilities, the general public. Once this principle is understood, there is no reason not to extend the measure to private owners of facilities which exist for public benefit. 